\title{
SPRAY VOLUME, DOSE AND TIME OF DAY OF GLYPHOSATE APPLICATION IN THE CONTROL OF Urochloa brizantha
}

\author{
Hugo M. Fialho e Moraes ${ }^{1}$, Lino Roberto Ferreira ${ }^{2}$, Wendel Magno de Souza ${ }^{2}$, Rodrigo \\ Magalhães Faria ${ }^{2}$, Marco A. Moreira de Freitas ${ }^{3}$ and Paulo Roberto Cecon ${ }^{4}$
}

\begin{abstract}
In order to optimize machinery use, the application of herbicides has been performed at different times of the day and night. Therefore, knowledge about the pesticide that will be used and how the spray volume and time of application affect the effectiveness of the product is very important. Thus, the objective of this work was to study the influence of spray volume and different time of application on the control of Urochloa brizantha by different doses of glyphosate. The treatments were arranged in a $5 \times 3 \times 2$ factorial scheme in a randomized block design with four replications. Five doses of glyphosate $(0 ; 1080 ; 1440 ; 1800$ and $2160 \mathrm{~g} \cdot \mathrm{ha}^{-1}$ a.e.), three times of application (morning, afternoon and evening) and two spray volumes $\left(50 \mathrm{and}^{\left.100 \mathrm{~L} \cdot \mathrm{ha}^{-1}\right)}\right.$ were evaluated. A control assessment was performed at 21 days after application, in addition to the accumulation of dry matter and the leaf area index on the regrowth. A satisfactory control of the grass was obtained for applications performed in the morning and afternoon, without interference of the volume applied and the doses tested. Evening application reduces the effectiveness of glyphosate in Urochloa brizantha burndown.
\end{abstract}

Additional keywords: Application technology, herbicide, spray

\section{RESUMEN}

\section{Volumen de pulverización, dosis y horario de aplicación de glifosato en el control de Urochloa brizantha}

Con el fin de optimizar el uso de la maquinaria, la aplicación de herbicidas se ha realizado en diferentes momentos del día y de la noche. Sin embargo, es muy importante el conocimiento sobre el pesticida que se utilizará y cómo el volumen de pulverización y el horario de aplicación pueden afectar la eficacia del tratamiento. Así, el objetivo de este trabajo fue estudiar la influencia del volumen de aspersión y los diferentes horarios de aplicación en el control de Urochloa brizantha para distintas dosis de glifosato. Los tratamientos se organizaron en un arreglo factorial de $5 \times 3 \times 2$ en un diseño de bloques al azar con cuatro repeticiones. Se evaluaron cinco dosis de glifosato $\left(0 ; 1080 ; 1440 ; 1800\right.$ y $2160 \mathrm{~g} \cdot \mathrm{ha}^{-1}$ e.a.), tres horarios de aplicación (mañana, tarde y noche) y dos volúmenes de aspersión $\left(50\right.$ y $\left.100 \mathrm{~L} \cdot \mathrm{ha}^{-1}\right)$. Se realizó una evaluación de control a los 21 días después de la aplicación, además de la acumulación de materia seca y el índice de área foliar en el rebrote. Se obtuvo un control satisfactorio de la hierba en las aplicaciones realizadas por la mañana y por la tarde, sin interferencia del volumen aplicado y las dosis probadas. La aplicación nocturna reduce la eficacia del control del glifosato sobre Urochloa brizantha.

Palabras clave adicionales: Herbicida, pulverización, tecnología de pulverización

\section{INTRODUCTION}

In order to optimize machinery and reduce costs, the application of herbicides has been performed at different periods of the day and night, although it is recommended that this practice should be better executed under favorable environmental conditions established such as, relative humidity above $55 \%$, speed wind up to 12 $\mathrm{km} \cdot \mathrm{h}^{-1}$ and temperature below $30{ }^{\circ} \mathrm{C}$ (Cunha et al.,

Received: January 26, 2021

Accepted: July 6, 2021

${ }^{1}$ Department of Agricultural Engineering, Federal University of Viçosa (UFV), Brazil.

e-mail: mfm.hugo@yahoo.com.br (corresponding author)

${ }^{2}$ Department of Agronomy, Federal University of Viçosa (UFV), Brazil. e-mail: 1roberto@ufv.br; wendelsouzaagro@gmail.com; rodrigo_faria159@yahoo.com.br

${ }^{3}$ Federal Institute of Goias, Brazil. e-mail: marco.freitas@ifgoiano.edu.br

${ }^{4}$ Department of Statistics, Federal University of Viçosa (UFV), Brazil. e-mail: cecon@ufv.br 
2016). However, these environmental conditions are not always encountered throughout the day.

Depending on the size of the farm, the planning of machinery availability and climatic conditions, applications of pesticides at different periods of the day is made necessary. Therefore, knowledge about the pesticide that will be used and how the volume and time of application affect the effectiveness of the product used is extremely important (Knoche, 1994; Montgomery et al., 2017).

Post-emergent herbicides are essential components in an integrated management of weeds, as well as in the burndown of areas for the introduction of the no-tillage system. In this system, efficient chemical control of cover crops is the key to success in the establishment of grain crops.

The genus Urochloa are the most used as cover crop (for straw production) and the cultivar Marandu has become the most relevant of its kind in Brazil (Timossi et al., 2006; Ribeiro et al., 2017). However, implementation of no-tillage systems requires that cover crops, either weeds or grasses, be eradicated. According to Costa et al. (2014), burndown is commonly performed with systemic herbicides based on glyphosate, since they are more efficient.

However, several studies have shown that the effectiveness of glyphosate can vary according to the time of application (Sellers et al., 2003; Waltz et al., 2004; Mohr et al., 2007) and spray volume (Creech et al., 2015). Its effectiveness has been reported to be decreased when the application is performed during the early morning and at evening, compared to the afternoon period (Martinson et al., 2002). However, such influence of application period may be imperceptible when using higher doses of glyphosate (Stewart et al., 2009; Almeida, 2018).

Although there are studies that suggest the influence of the spray volume on the effectiveness of glyphosate (Kogan and Zuñiga, 2001; Creech et al., 2015), several other works indicate that there is no effect of volume on efficiency in burndown (Almeida et al., 2014; 2015). Considering the hypothesis that the spray volume does not interfere with the action of glyphosate, several benefits can be mentioned: economy in water expenditure, reduced costs and time needed for spraying and optimization of the application period, thus favoring that phytosanitary treatments are employed at the most appropriate times.

Considering that there is still no consensus in the literature on the best time of day for glyphosate application, as well as the spray volume to be used, the objective of the present work was to study the influence of spray volume and different time of application on the control efficiency of Urochloa brizantha for different doses of glyphosate.

\section{MATERIALS AND METHODS}

The experiment was conducted in the Diogo Alves de Melo experimental field at the Universidade Federal de Viçosa (2046'05" latitude and $45^{\circ} 52^{\prime} 09^{\prime \prime}$ longitude and altitude of approximately $650 \mathrm{~m}$ ) in the period from November 2017 to September 2018.

A no-till seeder (Semeato SHM 11/13) was used, calibrated to sow $16 \mathrm{~kg} \cdot \mathrm{ha}^{-1}$ of seeds, with a cultural value of $36 \%$, of the species Urochloa brizantha 'Marandu', with $50 \mathrm{~cm}$ spacing between lines. At 85 days after sowing, a cut was made to stimulate the tillering of the Urochloa plants, in order to make them more robust. At 40 days after mowing, when the regrowth plants reached a height of approximately $60 \mathrm{~cm}$, the experimental plots, each one $4 \mathrm{~m}$ long and $3 \mathrm{~m}$ wide, were demarcated, and the treatments installed.

The treatments were arranged in a $5 \times 3 \times 2$ factorial scheme in a randomized block design with four replications. Five doses of glyphosate of Roundup original (SL), (0, 1080, 1440, 1800 and $2160 \mathrm{~g} \cdot \mathrm{ha}^{-1}$ a.e.), three times of application (morning, afternoon and evening) and two spray volumes (50 and $100 \mathrm{~L} \cdot \mathrm{ha}^{-1}$ ) were evaluated.

A backpack sprayer with constant pressure $\left(\mathrm{CO}_{2}\right)$, equipped with TT 11001 nozzles, working pressure of $3 \mathrm{kPa}$, flow rate of $0.4 \mathrm{~L} \cdot \mathrm{min}^{-1}$ and displacement speed of $4.8 \mathrm{~km} \cdot \mathrm{h}^{-1}$ was used. In order to apply a spray volume of $50 \mathrm{~L} \cdot \mathrm{ha}^{-1}$, spacing between nozzles of $100 \mathrm{~cm}$ was used, while to apply $100 \mathrm{~L} \cdot \mathrm{ha}^{-1}$, the spacing used was 50 $\mathrm{cm}$ between nozzles. At the time of application, two acrylic plates measuring $2.0 \mathrm{~m}$ in length and $1.6 \mathrm{~m}$ in height were used, which were laterally loaded on the edges between the plots, thus reducing potential risks of drift and contamination between plots.

The values of temperature, relative humidity and wind speed were measured with a pocket 
weather meter, model K3000 from Kestrel, at the beginning and at the end of each application
(Table 1). There was no rainfall in a period of at least $36 \mathrm{~h}$ after the installation of treatments.

Table 1. Environmental conditions at the time of application of the herbicide glyphosate during installation of treatments

\begin{tabular}{clccc}
\hline \multicolumn{2}{c}{ Application schedule } & Relative Humidity $(\%)$ & Temperature $\left({ }^{\circ} \mathrm{C}\right)$ & Wind speed $\left(\mathrm{km} \cdot \mathrm{h}^{-1}\right)$ \\
\hline \multirow{2}{*}{ Morning } & Start period: 8:10 a.m. & 70 & 25.7 & 4.0 \\
& End period: 9:20 a.m. & 54 & 28.2 & 2.0 \\
\hline \multirow{2}{*}{ Afternoon } & Start period: 1:45 p.m. & 52 & 30.2 & 5.0 \\
& End period: 3:00 p.m. & 50 & 29.7 & 4.0 \\
\hline \multirow{2}{*}{ Evening } & Start period: 7:15 p.m. & 71 & 23.3 & 1.2 \\
& End period: 8:30 p.m. & 77 & 22.4 & 1.0 \\
\hline
\end{tabular}

Water-sensitive papers (WSP) were randomly placed on the top of $U$. brizantha at each time of application for each spray volume, in order to quantify the percentage of coverage, droplet density (droplets per $\mathrm{cm}^{-2}$ ), and relative amplitude, that is, the difference in diameter for $\mathrm{DV}_{0.9}$ and $\mathrm{DV}_{0.1}$ of the sprayed volume divided by the $\mathrm{DV}_{0.5}$, where $\mathrm{DV}_{x x}$ represents the droplet diameter below which $x x$ fraction of the liquid volume is atomized. Subsequently, the labels were stored in paper envelopes and transferred to a glass desiccator with silica, thus avoiding the exposure of the labels to air humidity. The data extraction from the cards and their subsequent evaluation took place through the scanner and the DropScope program. The values of the WSP were averaged, in each volume and time of application, for comparison purposes.

For the analysis of the efficiency in burndown, a visual evaluation of the intoxication effects (control levels) of Urochloa brizantha plants was performed using a percentage scale of scores, in which 0 (zero) corresponded to no injury shown by the plants and 100 (one hundred) to the death of the plants, as suggested by the Brazilian Society of Weed Science - SBCPD (1995). The parameters used to establish control scores were: quantity and uniformity of injuries, inhibition of growth and mortality of plants.

The regrowth capacity of $U$. brizantha was tested by employing a mowing that was performed 42 days after application, and at 110 days after mowing, the accumulation of dry matter and the leaf area index (LAI) of the $U$. brizantha was determined, which was evaluated with the aid of a hollow metallic square, with a dimension of 0.50 $\mathrm{m} \times 0.50 \mathrm{~m}$, which was used twice in each plot. The plants were cut at ground level and placed in previously identified plastic bags. Then, the leaf area of the cut plants was determined with the aid of a bench meter (Li-Cor 3100) which enabled the determination of LAI.

After determining the leaf area, the samples were placed in a forced ventilation oven at $72{ }^{\circ} \mathrm{C}$ until constant mass. Subsequently, the material was weighed on a scale with a precision of 0.01 grams to obtain the accumulation of dry matter from the regrowth of $U$. brizantha in each treatment, which was later extrapolated per hectare.

Control assessments were performed at 7, 14, $21,28,35$ and 42 days after glyphosate application (DAA). The linear response plateau (LRP) discontinuous model adjustment procedure was used to find the best time to analyze control data. A trend of stability was observed between 15-21 DAA, being this the time used in the study of comparison of means and regression analysis for control.

The experimental data were subjected to analysis of variance and regression. For the spray volume and time of application factors, the Tukey test was used, at the $5 \%$ level to compare the averages. For the dose factor, regression was used and the models were chosen based on the significance of the regression coefficients, the determination coefficient $\left(\mathrm{R}^{2}\right)$ and the biological behavior.

\section{RESULTS AND DISCUSSION}

In all applications, a density greater than 50 droplets $\mathrm{cm}^{-2}$ was found, which is a number 
considered satisfactory for spraying a systemic product such as glyphosate (Magdalena, 2010). Similarly, the number of droplets deposited in applications performed with a spray volume of
$100 \mathrm{~L} \cdot \mathrm{ha}^{-1}$ was greater than 200 droplets $\cdot \mathrm{cm}^{-2}$. In addition, the applications performed at evening showed higher values of coverage, in relation to the morning and afternoon hours (Table 2).

Table 2. Average values referring to the analysis in DropScope software of the droplets deposited on the water-sensitive papers during glyphosate applications (Average of 16 labels)

\begin{tabular}{clccc}
\hline $\begin{array}{c}\text { Application volume } \\
\left(\mathrm{L} \cdot \mathrm{ha}^{-1}\right)\end{array}$ & $\begin{array}{c}\text { Time of } \\
\text { application }\end{array}$ & $\begin{array}{c}\text { Coverage } \\
(\%)\end{array}$ & $\begin{array}{c}\text { Density } \\
\left(\text { droplets } \cdot \mathrm{cm}^{-2}\right)\end{array}$ & $\begin{array}{c}\text { Relative } \\
\text { amplitude }\end{array}$ \\
\hline \multirow{3}{*}{50} & Morning & 7.1 & 53.2 & 0.96 \\
& Afternoon & 6.6 & 69.5 & 1.08 \\
& Evening & 22.6 & 315.6 & 1.56 \\
\hline \multirow{3}{*}{100} & Morning & 20.0 & 217.1 & 1.33 \\
& Afternoon & 23.3 & 265.8 & 1.29 \\
& Evening & 34.5 & 400.6 & 1.67 \\
\hline
\end{tabular}

Smaller values of relative amplitude were found in the applications employed in the morning (0.96) and in the afternoon (1.08) when using $50 \mathrm{~L} \cdot \mathrm{ha}^{-1}$ of spray volume. It is possible that the higher temperature and speed of the winds acting in these applications (Table 1), provided greater evaporation of the finer droplets and, consequently, reduced the value of the relative amplitude. The highest values of relative amplitude were found in evening applications, being 1.56 and 1.67 in volumes 50 and $100 \mathrm{~L} \cdot \mathrm{ha}^{-1}$, respectively.

The applications performed in the morning and afternoon periods, in the two spray volumes investigated, provided visual values of $U$. brizantha control higher than $90 \%$, considered satisfactory, according to the criteria of SBCPD (1995). On the other hand, the control found for the $1080 \mathrm{~g} \cdot \mathrm{ha}^{-1}$ a.e dose during evening applications was found to be 66 and $75 \%$ for spray volumes of 50 and $100 \mathrm{~L} \cdot \mathrm{ha}^{-1}$, respectively. These values are significantly lower than those found for morning and afternoon applications (Table 3), being less effective, even with greater application deposition (Figure 1). When the dose of $1440 \mathrm{~g} \cdot \mathrm{ha}^{-1}$ a.e. was used, the morning and afternoon applications were also significantly better than the evening applications for both volumes employed. Stopps et al. (2013) also found better weed control results when glyphosate was applied during the day.

Considering the spray volume, there was a significant difference between the applications performed, during evening, in the doses of 1080 and $1440 \mathrm{~g} \cdot \mathrm{ha}^{-1}$ a.e., with higher levels of control of U. brizantha when using a volume of 100 $\mathrm{L} \cdot \mathrm{ha}^{-1}$ (Table 3 ). For the other evaluated doses, there was no significant difference between the control values, regardless of the spray volume and the time of application.

The effect of the spray volume on the action of glyphosate is not very clear in the literature. The results found in the present research suggest that a greater leaf coverage may be interesting for a lower herbicide dose or with unfavorable environmental conditions, as in the case of evening application. Some authors have not found significant glyphosate responses in the control of $U$. riziziensis with the spray volume change (Almeida et al., 2014; 2015), corroborating the results found in the present study, when the applications were carried out in the morning and afternoon hours.

Creech et al. (2015) studying different application volumes $(47,70,94,140,187$, and $\left.281 \mathrm{~L} \cdot \mathrm{ha}^{-1}\right)$ of glyphosate, obtained better responses when volumes of 70 and $187 \mathrm{~L} \cdot \mathrm{ha}^{-1}$ were used. These results show that, under certain application conditions, it is possible to find a significant effect between different spray volumes, as occurred in this experiment, for the evening applications of glyphosate in doses of 1080 and $1440 \mathrm{~g} \cdot \mathrm{ha}^{-1}$ a.e. It is noteworthy that the use of reduced application volume, without loss of control effectiveness, allows cost reduction and allows spraying at the most crucial moments, especially in large areas.

The dry matter and LAI evaluated in the regrowth of $U$. brizantha, showed values 
significantly higher in the treatments of evening application at the dose of $1080 \mathrm{~g} \cdot \mathrm{ha}^{-1}$ a.e., regardless of the spray volume used (Tables 4 and 5). Considering the $1440 \mathrm{~g} \cdot \mathrm{ha}^{-1}$ dose of glyphosate, there was no significant difference between the application timing for the volume of $100 \mathrm{~L} \cdot \mathrm{ha}^{-1}$. However, for the same dose in the volume of 50 $\mathrm{L} \cdot \mathrm{ha}^{-1}$, higher values of dry matter and LAI for regrowth were observed when the evening spraying was employed, resulting in less control efficiency compared to the other times of application. According to Stewart et al. (2009) there are several environmental factors, such as air temperature, relative humidity, and light intensity that may explain variations in herbicide efficacy throughout the day.

Table 3. Mean control values (\%) of $U$. brizantha for the respective combinations of spray volume, dose and time of application.

\begin{tabular}{|c|c|c|c|c|c|c|c|c|c|c|}
\hline \multirow{4}{*}{$\begin{array}{c}\text { Time of } \\
\text { application }\end{array}$} & \multicolumn{10}{|c|}{ Glyphosate (g.ha- ${ }^{-1}$ a.e.) } \\
\hline & \multicolumn{2}{|c|}{0} & \multicolumn{2}{|c|}{1080} & \multicolumn{2}{|c|}{1440} & \multicolumn{2}{|c|}{1800} & \multicolumn{2}{|c|}{2160} \\
\hline & \multicolumn{10}{|c|}{ Spray volume $\left(\mathrm{L} \cdot \mathrm{ha}^{-1}\right)$} \\
\hline & 50 & 100 & 50 & 100 & 50 & 100 & 50 & 100 & 50 & 100 \\
\hline Morning & $0 \mathrm{Aa}$ & $0 \mathrm{Aa}$ & $94 \mathrm{Aa}$ & $96 \mathrm{Aa}$ & $99 \mathrm{Aa}$ & 96Аa & $99 \mathrm{Aa}$ & $97 \mathrm{Aa}$ & $98 \mathrm{Aa}$ & $96 \mathrm{Aa}$ \\
\hline Afternoon & $0 \mathrm{Aa}$ & $0 \mathrm{Aa}$ & $94 \mathrm{Aa}$ & $95 \mathrm{Aa}$ & $96 \mathrm{Aa}$ & $96 \mathrm{Aa}$ & $98 \mathrm{Aa}$ & $97 \mathrm{Aa}$ & $97 \mathrm{Aa}$ & $97 \mathrm{Aa}$ \\
\hline Evening & $0 \mathrm{Aa}$ & $0 \mathrm{Aa}$ & $66 \mathrm{Bb}$ & $75 \mathrm{Ba}$ & $73 \mathrm{Bb}$ & $86 \mathrm{Ba}$ & $92 \mathrm{Aa}$ & $94 \mathrm{Aa}$ & $92 \mathrm{Aa}$ & $93 \mathrm{Aa}$ \\
\hline
\end{tabular}

Means followed by the same uppercase letter in the column and lowercase in the row, for each dose, do not differ at $5 \%$ probability, using the Tukey test
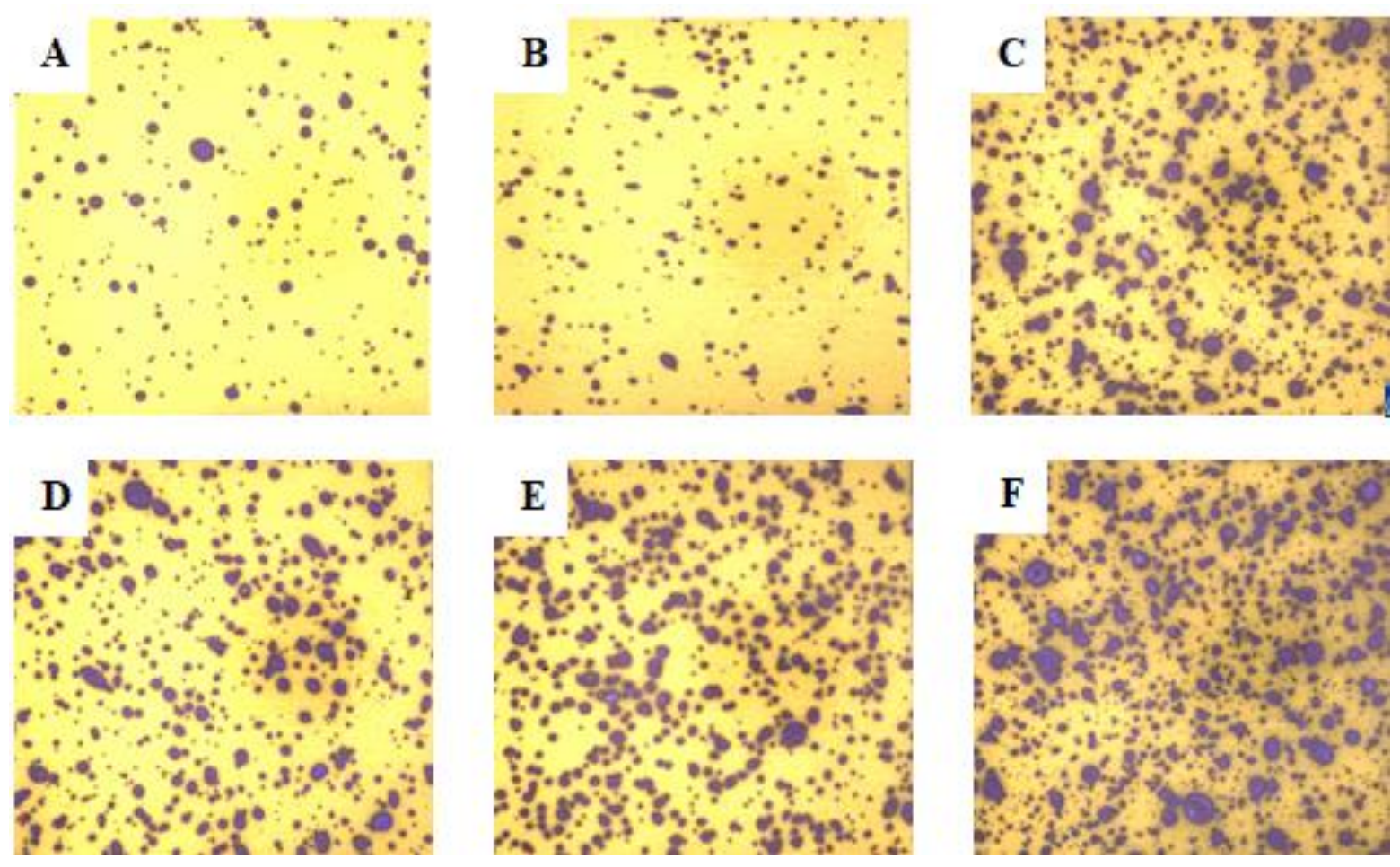

Figure 1. Examples of water-sensitive papers used to check the deposition of droplets in the morning (A), afternoon (B) and evening (C) applications for the volume of $50 \mathrm{~L} \mathrm{ha}^{-1}$ and morning (D), afternoon (E) and evening (F) for $100 \mathrm{~L} \cdot \mathrm{ha}^{-1}$

The analysis of the effect of spray volume on $U$. brizantha control, as well as dry matter and LAI on regrowth, revealed better responses for applications carried out with $100 \mathrm{~L} \cdot \mathrm{ha}^{-1}$, when doses 1080 and $1440 \mathrm{~g} \cdot \mathrm{ha}^{-1}$ a.e. were used and, comparing only evening applications. However, 
this effect was not observed when doses 1800 and $2160 \mathrm{~g} \cdot \mathrm{ha}^{-1}$ a.e. were used, regardless of the time of application and the spray volume (Tables 4 and 5).

Table 4. Average values of dry matter $\left(\mathrm{kg} \cdot \mathrm{ha}^{-1}\right)$ in the regrowth of $U$. brizantha for the respective combinations of spray volume, dose and time of application

\begin{tabular}{|c|c|c|c|c|c|c|c|c|c|c|}
\hline \multirow{4}{*}{$\begin{array}{c}\text { Time of } \\
\text { application }\end{array}$} & \multicolumn{10}{|c|}{ Glyphosate (g.ha ${ }^{-1}$ a.e.) } \\
\hline & \multicolumn{2}{|c|}{0} & \multicolumn{2}{|c|}{1080} & \multicolumn{2}{|c|}{1440} & \multicolumn{2}{|c|}{1800} & \multicolumn{2}{|c|}{2160} \\
\hline & \multicolumn{10}{|c|}{ Spray volume $\left(\mathrm{L} \cdot \mathrm{ha}^{-1}\right)$} \\
\hline & 50 & 100 & 50 & 100 & 50 & 100 & 50 & 100 & 50 & 100 \\
\hline Morning & $2693 \mathrm{Aa}$ & $2436 \mathrm{Aa}$ & $0 \mathrm{Ba}$ & $0 \mathrm{Ba}$ & $0 \mathrm{Ba}$ & $0 \mathrm{Aa}$ & $0 \mathrm{Aa}$ & $0 \mathrm{Aa}$ & $0 \mathrm{Aa}$ & $0 \mathrm{Aa}$ \\
\hline Afternoon & $2412 \mathrm{Aa}$ & $2352 \mathrm{Aa}$ & $0 \mathrm{Ba}$ & $0 \mathrm{Ba}$ & $0 \mathrm{Ba}$ & $0 \mathrm{Aa}$ & $0 \mathrm{Aa}$ & $0 \mathrm{Aa}$ & $0 \mathrm{Aa}$ & $0 \mathrm{Aa}$ \\
\hline Evening & $2506 \mathrm{Aa}$ & $2627 \mathrm{Aa}$ & $901 \mathrm{Aa}$ & $458 \mathrm{Ab}$ & $685 \mathrm{Aa}$ & $115 \mathrm{Ab}$ & $0 \mathrm{Aa}$ & $10 \mathrm{Aa}$ & $0 \mathrm{Aa}$ & $0 \mathrm{Aa}$ \\
\hline
\end{tabular}

Table 5. Mean LAI values in the regrowth of $U$. brizantha for the respective combinations of spray volume, dose and time of application

\begin{tabular}{|c|c|c|c|c|c|c|c|c|c|c|}
\hline \multirow{4}{*}{$\begin{array}{l}\text { Time of } \\
\text { application }\end{array}$} & \multicolumn{10}{|c|}{ Glyphosate (g·ha ${ }^{-1}$ a.e. $)$} \\
\hline & \multicolumn{2}{|c|}{0} & \multicolumn{2}{|c|}{1080} & \multicolumn{2}{|c|}{1440} & \multicolumn{2}{|c|}{1800} & \multicolumn{2}{|c|}{2160} \\
\hline & \multicolumn{10}{|c|}{ Spray volume $\left(\mathrm{L} \cdot \mathrm{ha}^{-1}\right)$} \\
\hline & 50 & 100 & 50 & 100 & 50 & 100 & 50 & 100 & 50 & 100 \\
\hline Morning & $2.49 \mathrm{Aa}$ & $2.35 \mathrm{Aa}$ & $0.0 \mathrm{Ba}$ & $0.0 \mathrm{Ba}$ & $0.0 \mathrm{Ba}$ & $0.0 \mathrm{Aa}$ & $0.0 \mathrm{Aa}$ & $0.0 \mathrm{Aa}$ & $0.0 \mathrm{Aa}$ & $0.0 \mathrm{Aa}$ \\
\hline Afternoon & $2.24 \mathrm{Aa}$ & $2.25 \mathrm{Aa}$ & $0.0 \mathrm{Ba}$ & $0.0 \mathrm{Ba}$ & $0.0 \mathrm{Ba}$ & $0.0 \mathrm{Aa}$ & $0.0 \mathrm{Aa}$ & $0.0 \mathrm{Aa}$ & $0.0 \mathrm{Aa}$ & $0.0 \mathrm{Aa}$ \\
\hline Evening & $2.30 \mathrm{Aa}$ & $2.49 \mathrm{Aa}$ & $0.79 \mathrm{Aa}$ & $0.39 \mathrm{Ab}$ & $0.61 \mathrm{Aa}$ & $0.11 \mathrm{Ab}$ & $0.0 \mathrm{Aa}$ & $0.01 \mathrm{Aa}$ & $0.0 \mathrm{Aa}$ & $0.0 \mathrm{Aa}$ \\
\hline
\end{tabular}

Means followed by the same uppercase letter in the column and lowercase in the row, for each dose, do not differ at $5 \%$ probability, using the Tukey test

The analysis of the control of $U$. brizantha as a function of dose, for the respective combinations of times of application and volumes indicates a tendency towards stabilization in the percentages of control from the doses of 1083, 1098 and 1314 $\mathrm{g} \cdot \mathrm{ha}^{-1}$ a.e. with $100 \mathrm{~L} \cdot \mathrm{ha}^{-1}$, in the morning, afternoon and evening, respectively. In the application with a volume of $50 \mathrm{~L} \cdot \mathrm{ha}^{-1}$, the respective doses were 1132,1115 and 1687 $\mathrm{g} \cdot \mathrm{ha}^{-1}$ a.e. (Figure 2). These results show that it is possible to employ the application of the herbicide, with lower doses, respecting the best time for application and spray volume, aiming at the practice of an environmentally correct and economically viable agriculture.

The regression equation for the accumulation of dry matter and the LAI in the regrowth of $U$. brizantha indicates that there is sufficient control from the dose $1080 \mathrm{~g} \cdot \mathrm{ha}^{-1}$ a.e. for the morning and afternoon applications, regardless of the volume studied (Figures 3 and 4). However, for the evening application, a similar result of $U$. brizantha control is achieved only with doses of 1287 and $1877 \mathrm{~g} \cdot \mathrm{ha}^{-1}$ a.e. in the spray volumes of 100 and $50 \mathrm{~L} \cdot \mathrm{ha}^{-1}$, respectively (Figure 3). Applicators should try to avoid early morning (6:00) and evening hour applications of glyphosate (Martinson et al., 2005).

Although greater deposition was found for the evening applications, morning and afternoon applications showed better control results when used at doses of 1080 and $1440 \mathrm{~g} \cdot \mathrm{ha}^{-1}$ a.e. These results suggest that the interactions that may occur between the herbicide, environmental conditions, time of application, spray volume and plant (target), may be decisive for a quality and environmentally correct burndown.

In this sustainable context, the lowest dose of glyphosate applied in the morning and afternoon, in both investigated volumes, presented 
satisfactory results and there was no significant difference for the response variables when compared to the other doses used. Vidal et al. (2014) corroborate this idea and claim that simply increasing the dose of herbicides has not been the most appropriate procedure to ensure the effectiveness of control. Rodrigues et al. (2018) emphasize that the correct dose in burndown can vary according to the species and stage of development. In addition, plants of the same species that are subjected to different environmental conditions, may have greater or lesser sensitivity to the same dose of herbicide (Pereira et al., 2010).
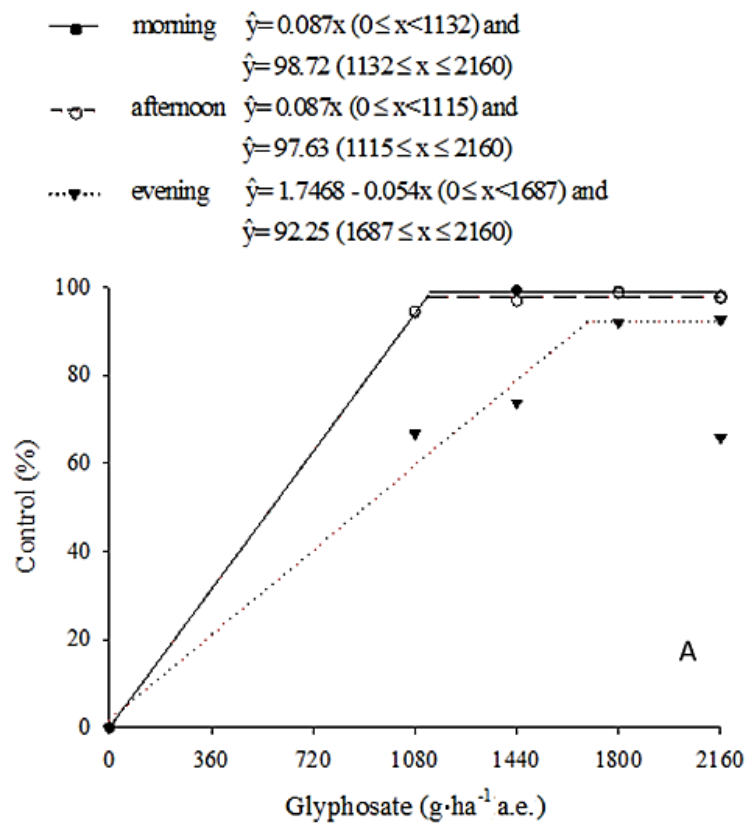
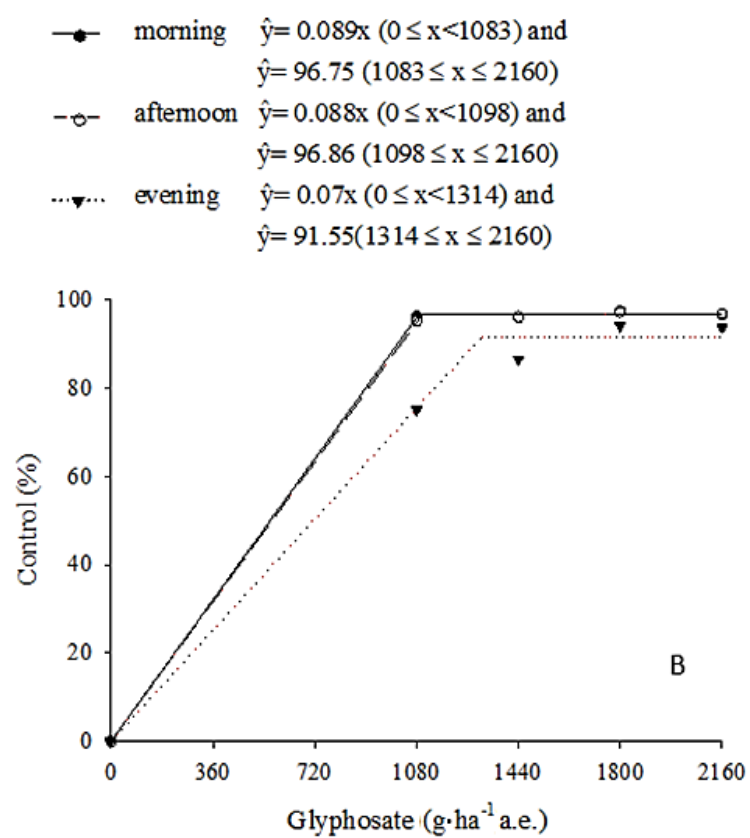

Figure 2. Control at $21 \mathrm{DAA}$, of $U$. brizantha, as a function of glyphosate dose, for the different time of application using the volume of $50 \mathrm{~L} \cdot \mathrm{ha}^{-1}(\mathrm{~A})$ and $100 \mathrm{~L} \cdot \mathrm{ha}^{-1}(\mathrm{~B})$
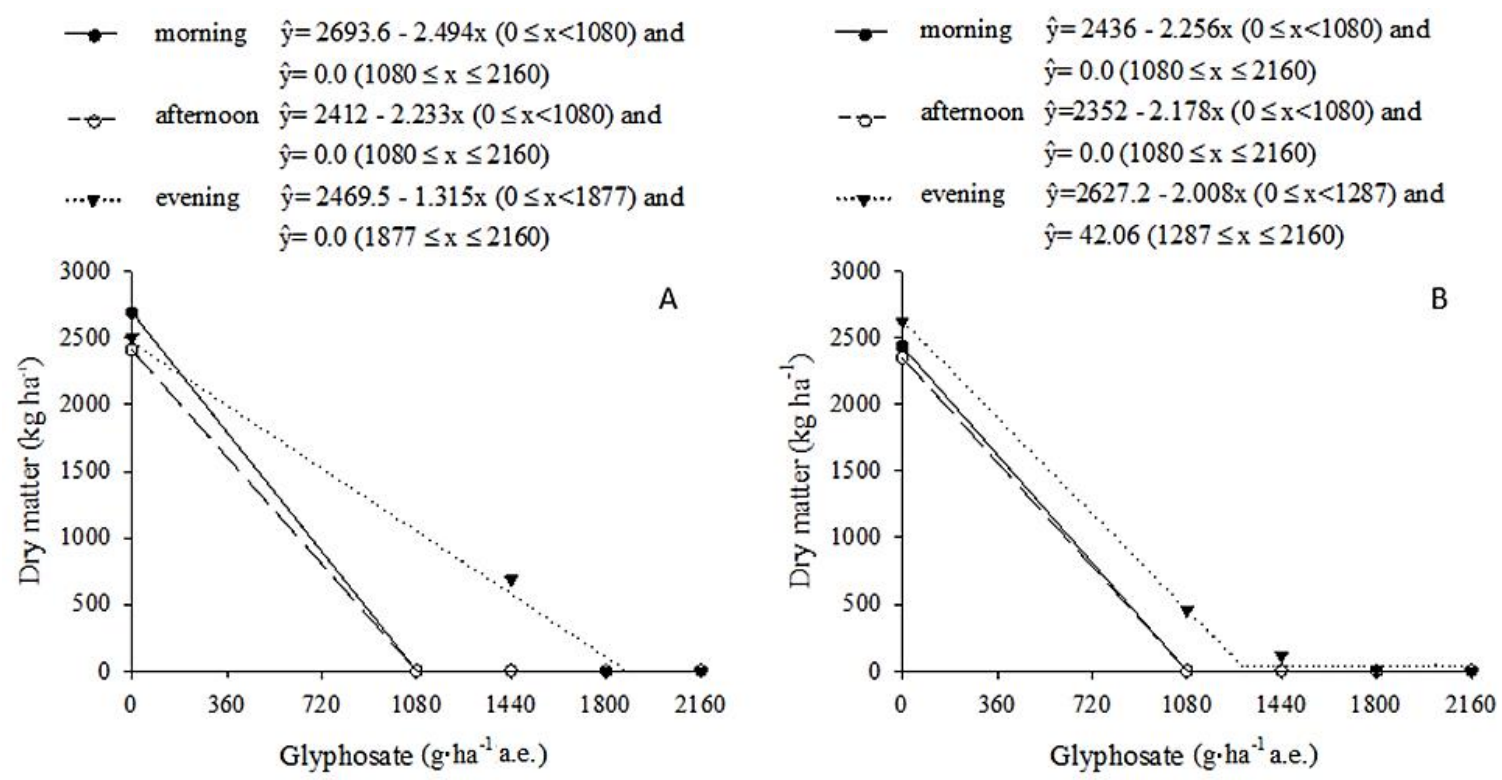

Figure 3. Dry matter $\left(\mathrm{kg} \cdot \mathrm{ha}^{-1}\right)$ of $U$. brizantha at the end of the experiment, as a function of glyphosate dose, for the different time of application using the volume of $50 \mathrm{~L} \cdot \mathrm{ha}^{-1}(\mathrm{~A})$ and $100 \mathrm{~L} \cdot \mathrm{ha}^{-1}$ (B) 

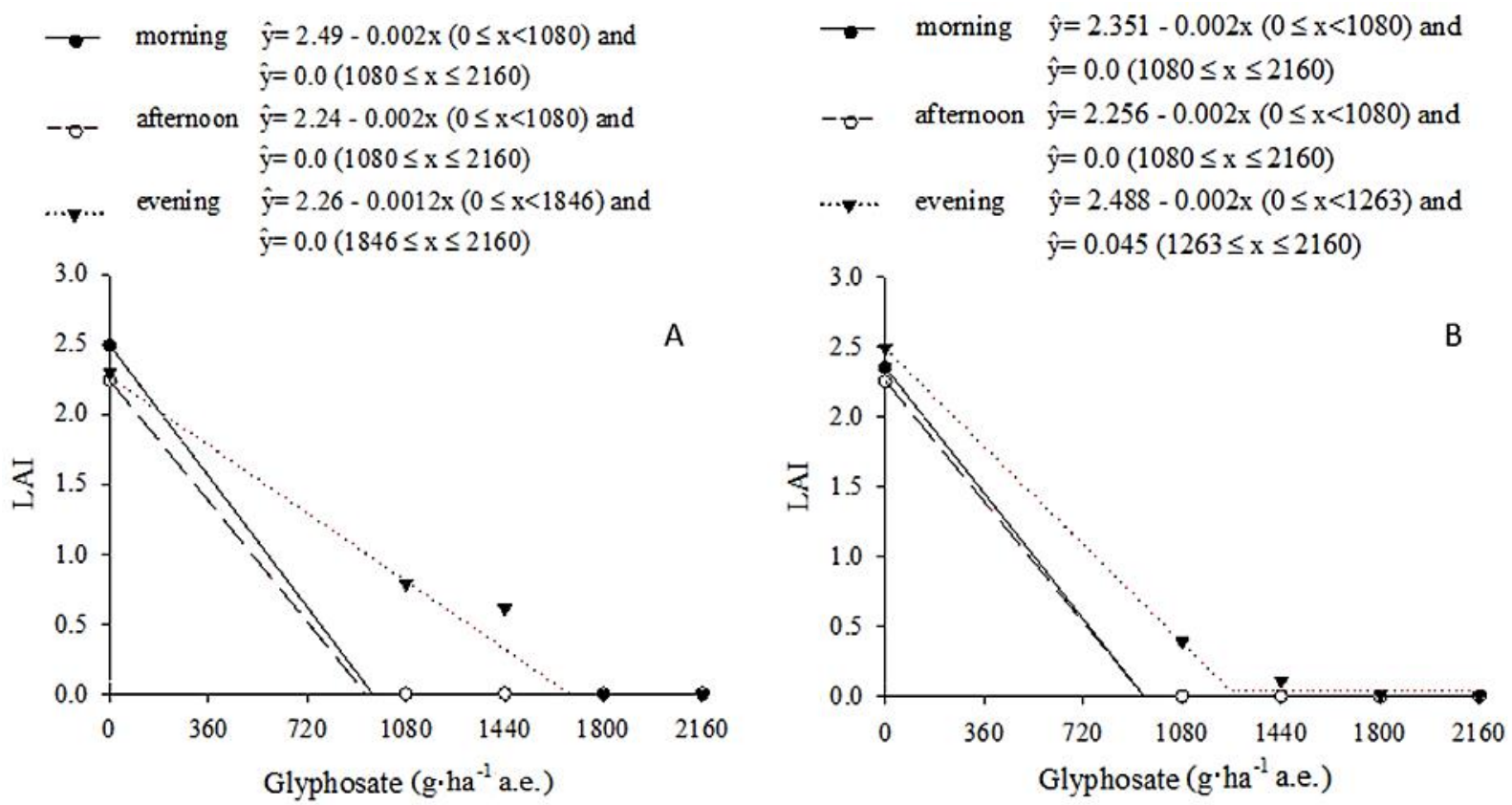

Figure 4. LAI of $U$. brizantha at the end of the experiment, as a function of glyphosate dose, for the different time of application using the volume of $50 \mathrm{~L} \cdot \mathrm{ha}^{-1}$ (A) and $100 \mathrm{~L} \cdot \mathrm{ha}^{-1}$ (B)

Considering $U$. brizantha as a $\mathrm{C} 4$ metabolism plant, the absorption and translocation of glyphosate may have been favored in the morning and afternoon applications, since they were performed in the presence of light and in periods of higher temperature, when compared to evening applications. Santos et al. (2013), by studying shaded environments, found greater activity of glyphosate in plants that were in presence of light. Sharkhuu et. al (2014) and Stopps et al. (2013) emphasize that the application of glyphosate during sunny periods favors its activity, compared to applications performed at evening and at night. Vidal et al. (2014) suggest that in plant species adapted to summer, the increase in air temperature to optimum plant metabolism values favors the performance of the herbicide glyphosate, corroborating the results of this experiment. The increase in air temperature is able to alter the cuticular wax of the leaves and increase the fluidity of the plasma membrane, resulting in greater herbicide absorption and translocation (Hess and Falk, 1990; Johnson and Young, 2002).

According to Rodrigues et al. (2018), several doses of glyphosate have been tested for the control of cover plants and the correct dose in the burndown of these plants can vary according to the species and stage of development. The results of the current study suggest that the application timing of glyphosate and the spray volume have also to be observed.

\section{CONCLUSION}

The time of day for glyphosate application influences the burndown efficacy of Urochloa brizantha. In the present study, the dose of 1080 $\mathrm{g} \cdot \mathrm{ha}^{-1}$ a.e., applied in the morning and afternoon, regardless of the spray volume, was efficient in the burndown. Evening application reduces the effectiveness of glyphosate in $U$. brizantha burndown.

\section{ACKNOWLEDGEMENTS}

This study was financed in part by the Coordenação de Aperfeiçoamento de Pessoal de Nível Superior - Brasil (CAPES) - Finance Code 001 and by the Conselho Nacional de Desenvolvimento Científico e Tecnológico (CNPq, The Brazilian National Council for Scientific and Technological Development).

\section{LITERATURE CITED}

1. Almeida, D.P. 2018. Volume de aplicação reduzido e concentrações de glyphosate na 
calda em condições meteorológicas distintas para dessecação de cobertura vegetal em sistema de plantio direto. Thesis. Universidade Estadual Paulista-UNESP, Jaboticabal, Brazil. $75 \mathrm{p}$.

2. Almeida, D.P., P.C. Timossi, S.F. Lima, U.R. Silva and E.F. Reis. 2014. Condições atmosféricas e volumes de aplicação na dessecação de Urochloa ruziziensis e vegetação espontânea. Revista Brasileira de Herbicidas 13(3): 245-251.

3. Almeida, D.P., P.C. Timossi, S.F. Lima, U.R. Silva and E.F. Reis. 2015. Droplets size categories and application volumes in burndown of plant covers. Brazilian Herbicide Journal 14(1): 73-82.

4. Creech, C.F., R.S. Henry, R. Werle, L.D. Sandell, A.J. Hewitt and G.R. Kruger. 2015. Performance of postemergence herbicides applied at different carrier volume rates. Weed Technology 29(3): 611-624.

5. Costa, N.V., D.A. Sontag, C.A. Scariot, G.R. Pereira and E.S. Vasconcelos. 2014. Doses de paraquat e volumes de calda na dessecação de Brachiaria ruziziensis antes do cultivo do milho safrinha. Revista Brasileira de Herbicidas 13(2): 143-155.

6. Cunha, J.P. A.R., J.N. P. Pereira, L.A. Barbosa and C.R. Silva. 2016. Pesticide application windows in the region of Uberlândia-MG, Brazil. Bioscience Journal 32(2): 403-411.

7. Hess, F.D. and R.H. Falk. 1990. Herbicide deposition on leaf surfaces. Weed Science 38(3): 280-288.

8. Johnson, B.C. and B.G. Young. 2002. Influence of temperature and relative humidity on the foliar activity of mesotrione. Weed Science 50(2): 157-161.

9. Knoche, M. 1994. Effect of droplet size and carrier volume on performance of foliageapplied herbicides. Crop Protection 13(3): 163178.

10.Kogan, M. and M. Zúñiga. 2001. Dew and spray volume effect on glyphosate efficacy. Weed Technology 15(3): 590-593.

11. Magdalena J.C. 2010. Tecnología de Aplicación de Agroquímicos. CYTED. Red Pulso. Universidad Nacional del Sur, Bahía Blanca, Argentina. https://n9.cl/xkoqr (retrieved Jul. 6, 2021)

12.Martinson, K.B., R.B. Sothern, W.L. Koukkari, B. R. Durgan and J.L. Gunsolus. 2002. Circadian response of annual weeds to glyphosate and glufosinate. Chronobiology International 19(2): 405-422.

13.Martinson, K.B., B.R. Durgan, J.L. Gunsolus and R. B. Sothern. 2005. Time of day of application effect on glyphosate and glufosinate efficacy. Crop Management 4(1): 1-7.

14.Mohr, K., B.A. Sellers and R. J. Smeda. 2007. Application time of day influences glyphosate efficacy. Weed Technology 21(1): 7-13.

15.Montgomery G.B., J.A. Treadway, J.L. Reeves and L.E. Steckel. 2017. Effect of time of day of application of 2,4-D, dicamba, glufosinate, paraquat, and saflufenacil on horseweed (Conyza canadensis) control. Weed Technology 31(4): 550-556.

16.Pereira, M.R.R., D. Martins, J.I.C.D. Silva, A.C.P.R. Costa and A.E. Klar. 2010. Efeito de herbicidas sobre plantas de Brachiaria plantaginea submetidas a estresse hídrico. Planta Daninha 28(spe): 1047-1058.

17.Ribeiro Júnior, N.G., I.V. Silva, C.F. Araújo, O.S. Fagundes and W. Gervazio. 2017. Anatomia e morfometria de raízes e folhas de Urochloa brizantha cv. Marandu em diferentes estádios de acometimento da síndrome da morte das pastagens. Iheringia, Série Botânica 72(1): 127-132.

18.Rodrigues, G.S., R.D. Medeiros, J.A.A. Albuquerque, O.J. Smiderle, J. M.A. Alves and A.A. Silva. 2018. Manejo químico de Urochloa ruziziensis consorciado com soja na savana de Roraima. Revista Brasileira de Herbicidas 17(2): 1-11.

19. Santos Júnior, A., L.D. Tuffi Santos, G.A. Costa, E.A. Barbosa, G.L.D. Leite, V.D. Machado and L.R. Cruz. 2013. Manejo da tiririca e trapoeraba com glyphosate em ambientes sombreados. Planta Daninha 31(1): 213-221.

20.SBCPD (Sociedade Brasileira da Ciência das Plantas Daninhas). 1995. Procedimentos para instalação, avaliação e análise de experimentos com herbicidas. Londrina, Paraná, Brasil. https://n9.cl/7pgw2 (retrieved July 6, 2021). 
21.Sellers, B.A., R.J. Smeda and W.G. Johnson. 2003. Diurnal fluctuations and leaf angle reduce glufosinate efficacy. Weed Technology 17(2): 302-306.

22.Sharkhuu, A., M.L. Narasimhan, J.S. Merzaban, R.A. Bressan, S. Weller and C. Gehring. 2014. A red and far-red light receptor mutation confers resistance to the herbicide glyphosate. The Plant Journal 78(6): 916926.

23.Stewart, C.L., R.E. Nurse and P.H. Sikkema. 2009. Time of day impacts POST weed control in corn. Weed Technology 23(3): 346-355.

24.Stopps, G.J., R.E. Nurse and P.H. Sikkema. 2013. The effect of time of day on the activity of postemergence soybean herbicides. Weed Technology 27(4): 690-695.

25.Timossi, P.C., J.C. Durigon and G.J. Leite. 2006. Eficácia de glyphosate em plantas de cobertura. Planta Daninha 24(3): 475-480.

26.Vidal, R. A., F. Pagnoncelli Jr., M. V. Fipke, A. R. S. Queiroz, H. V. H. Bittencourt and M. M. Trezzi. 2014. Fatores ambientais que afetam a eficácia de glifosato: síntese do conhecimento. Pesticidas: Revista de Ecotoxicologia e Meio Ambiente 24: 43-52.

27.Waltz, A.L., A.R. Martin, F.W. Roeth and J.L. Lindquistg. 2004. Glyphosate efficacy on velvetleaf varies with application time of day. Weed Technology 18(4): 931-939. 